\title{
SISTEM PENETAPAN DAN PEMUNGUTAN PAJAK SARANG BURUNG WALET DI KABUPATEN MINAHASA UTARA
}

\author{
Meybi Marliane Pongoh ${ }^{1}$ \\ Ventje Ilat ${ }^{2}$ \\ Fakultas Ekonomi dan Bisnis, Jurusan Akuntansi \\ Universitas Sam Ratulangi Manado \\ email: ${ }^{1}$ pongoh.meybi@yahoo.com \\ 2 ventjeilat@yahoo.com
}

\begin{abstract}
Local tax is an obligatory contribution which is made by the region government for taxable individual or institution without an equal directly rewards, which is used to sponsoring goverment performance and development. Taxation of swift's nest is a tax on the extraction and exploitation of swift's nest. This thesis discusses about system of establishment and collection of swift's nest which aims to determine a fair taxation system accordance with fairness collection tax principle and it's mechanism undertaken by govermentas know as department of revenue MINUT. The analytical method of this thesis is qualitative descriptive. The result of this research are show that the determination of swift's nest taxation is already accordance with it's fairness collection tax principle and it's already well underway. So that the target of swift's nest taxation revenue is already realized. Although, there are some constraints in term of collecting swift's nest taxation at MINUT.
\end{abstract}

Keywords : Swift's Nest Taxation, Tax's astablisment, Tax's Collection. 


\section{Latar Belakang}

\section{PENDAHULUAN}

Dengan berlakunya Undang-Undang Nomor 28 Tahun 2009 tentang Pajak Daerah dan Retribusi Daerah, daerah mendapat peluang untuk menggali secara maksimal dana yang ada di daerahnya, dengan tetap memperhatikan kondisi ekonomi dan sosial daerah dalam undang-undang tersebut, pemerintah daerah diizinkan untuk memungut beberapa jenis pajak baru, di antaranya pajak sarang burung walet.

Salah satu pajak yang memberikan kontribusi terhadap negara adalah Pajak Sarang burung walet. Pajak Sarang burung walet adalah pajak atas kegiatan pengambilan dan atau pengusahaan sarang burung walet. Burung Walet yaitu satwa yang termasuk marga collocalia, yaitu collocalia fuchliap haga, collocalia maxina, collocalia esculanta, dan collocalia linchi.

Usaha Sarang Burung Walet merupakan usaha yang dapat mendatangkan penghasilan yang lumayan karenakan harga (nilai) Sarang tersebut yang cukup mahal, dari hasil pengusaha yang bisa menghasilkan pendapatan yang besar dari usaha sarang burung walet ini. Melihat potensi penghasilan dari sarang burung walet yang cukup besar, maka pemerintah tergerak untuk memungut pajak terhadap usaha tersebut. Tujuan utama pemungutannya adalah untuk mendukung Pendapatan Asli Daerah (PAD).

Pendapatan Asli Daerah (PAD) merupakan salah satu wujud nyata dari tingkat kemandirian daerah dengan tingkat kemampuan pemerintah daerah dalam memobilisasi sumber-sumber dana daerah untuk melaksanakan pembangunan daerah guna meningkatkan pelayanan dan kesejahteraan masyarakat. Peningkatan kesejahteraan masyarakat ditandai dengan membayar pajak dan retribusi daerah.

Pemungutan pajak yang adil dan efisien harus diterapkan terhadap semua sektor pemungutannya, termasuk pada pajak sarang burung walet. Ketika pemungutan pajak dan sarang burung walet dilaksanakan dengan adil dan efisien, maka nantinya akan berpengaruh terhadap hasil yang diterima. Pemungutan pajak yang adil, pengaruh yang dapat dirasakan yaitu dengan bertambahnya jumlah pengusaha sarang burung walet yang melaporkan usahanya untuk dikenakan pajak di dinas pendapatan daerah. Ketika makin banyak melapor maka hal ini akan berpengaruh pada realisasi pendapatan pajak dari sarang burung walet. Karena penerimaan pajak sarang burung walet tergolong kecil di antara pajak-pajak yang lain, namun dengan adanya syarat pemungutan yang efisien maka pajak sarang burung walet ini akan terasa berpengaruh terhadap penerimaan kas daerah.

\section{Tujuan Penelitian}

Tujuan penelitian ini untuk mengetahui bagaimana sistem penetapan pajak dan pemungutannya terhadap Pajak Sarang Burung Walet di Kabupatan Minahasa Utara.

\section{Konsep Akuntansi}

\section{TINJAUAN PUSTAKA}

Akuntansi adalah suatu seni pencatatan, pengklasifikasian, dan pengikhtisaran dalam cara yang signifikan dan satuan mata uang, transaksi - transaksi dan kejadian - kejadian yang paling tidak sebagian diantaranya, memiliki sifat keuangan, dan selanjutnya menginterpretasikan hasilnya. American institute of certified public accountants dalam (Belkaoui, 2011:50). Secara umum, akuntansi (accounting) dapat diartikan sebagai sistem informasi yang menyediakan laporan untuk para pemangku kepentingan mengenai aktivitas ekonomi dan kondisi perusahaan (Reeve. et, al. 2013:9).

\section{Konsep Pajak}

Pajak merupakan sumber utama penerimaan negara dan daerah. Tanpa pajak, sebagian besar kegiatan pemerintahan sulit untuk dapat dilaksanakan. Pelayanan yang diberikan pemerintah merupakan suatu kepentingan umum (public utilities) untuk kepuasan bersama, sehingga pajak yang mengalir dari masyarakat akhirnya kembali lagi untuk masyarakat (Waluyo, 2010:4). Penggunaan uang pajak meliputi belanja pegawai sampai dengan pembiayaan berbagai proyek pembangunan sarana umum seperti jalanjalan, jembatan, listrik, air, sekolah, rumah sakit, dan sebagainya. Uang pajak juga digunakan untuk pembiayaan dalam rangka memberikan rasa aman bagi seluruh lapisan masyarakat. Setiap warga negara mulai saat dilahirkan sampai dengan meninggal dunia, menikmati fasilitas atau pelayanan dari pemerintah 
yang semuanya dibiayai dengan uang yang berasal dari pajak. Dengan demikian jelas bahwa peranan pajak bagi suatu negara menjadi sangat dominan dalam menunjang jalannya roda pemerintahan dan pembiayaan pembangunan, dengan perkataan lain harus dapat mendorong pengembangan ekonomi jadi lebih baik (Ilyas, 2010:3)

\section{Pajak Daerah}

Secara umum, pajak daerah adalah kontribusi wajib kepada daerah yang terutang oleh orang pribadi atau badan yang bersifat memaksa berdasarkan Undang-Undang, dengan tidak mendapatkan imbalan secara langsung dan digunakan untuk keperluan daerah bagi sebesar-besarnya kemakmuran rakyat (TMBooks, 2013:7). Selain itu, pajak daerah juga memiliki arti yang hampir sama, yaitu pajak yang dipungut daerah berdasarkan peraturan pajak yang ditetapkan oleh daerah untuk kepentingan pembiayaan rumah tangga pemerintah daerah tersebut. (Mardiasmo, dikutip dalam Samudra, 2015:68).

Menurut (Ismail, 2011), pajak daerah yang baik pada prinsipnya harus dapat memenuhi dua kriteria yaitu:

a) Pajak daerah harus memberikan pendapatan yang cukup tinggi bagi daerah dengan derajat otonomi fiskal yang dimilikinya.

b) Pajak daerah harus secara jelas berdampak pada tanggung jawab fiskal yang dimiliki oleh pemerintah daerah yang bersangkutan.

\section{Pajak Sarang Burung Walet}

Pajak Sarang Burung Walet adalah pajak atas kegiatan pengambilan dan/atau penguasaan sarang burung walet. Burung Walet adalah satwa yang termasuk marga collocalia, yaitu collocalia fuchliap haga, collocalia maxina, collocalia esculanta, dan collocalia linchi.

\section{Penelitian Terdahulu}

Nurhidayati (2010) dengan judul Evaluasi Penerimaan Pajak Sarang Burung Walet. Tujuan penelitian ini untuk Mengevaluasi pungutan pajak sarang burung walet di kota Bengkulu berdasarkan kriteria pemungutan pajak yang baik berdasarkan prinsip Smith Canons menggunakan metode Kualitatif. Hasil penelitian Evaluasi pajak sarang burung walet ini dilakukan melalui penilaian berdasarkan kriteria pemungutan pajak daerah, selain itu dilakukan pula perhitungan potensi penerimaan pajak sarang burung walet. Hasil perhitungan potensi yang didapatkan, penerimaan pajak sarang burung walet ini sudah mempunyai potensi yang sangat besar sehingga sangat memberikan kontribusi yang tinggi pada PAD. Hafshah Muhardiana (2011) dengan judul Kontribusi Pajak sarang burung walet dalam meningkatkan PAD Kab. Kepulauan meranti. Tujuan penelitian ini Untuk mengetahui pelaksanaan pemungutan pajak sarang burung. Menggunakan metode kualitatif. Hasil penelitian Pelaksanaan pemungutan pajak telah berjalan dengan baik dan sudah terealisasi sesuai dengan target yang di anggarkan.

\section{Jenis Penelitian}

\section{METODE PENELITIAN}

Berdasarkan judul penelitian yang ada, penelitian ini merupakan penelitian deskriptif. Metode penelitian dinamakan sebagai metode baru (Sugiyono, 2012:7). Secara umum, penelitian deskriptif adalah sebuah metode dalam meneliti suatu objek, suatu kondisi, suatu sistem pemikiran ataupun suatu peristiwa yang terjadi. Menurut (Sugiyono, 2012: 13) penelitian deskriptif dilakukan untuk mengetahui nilai variabel mandiri, baik satu variabel atau lebih (independen) tanpa membuat perbandingan, atau menghubungkan dengan variabel lain. Tujuan dari penelitian deskriptif adalah untuk membuat suatu deskripsi, gambaran, ataupun penjelasan secara sistematis, faktual, dan akurat mengenai fakta-fakta dan sifat-sifat dari fenomena atau peristiwa yang diselidiki. 


\section{Tempat dan Waktu Penelitian}

Lokasi Penelitian di Dinas Pendapatan Daerah Kabupaten Minahasa Utara, dengan waktu penelitian dimulai pada bulan Februari sampai dengan bulan April 2016.

\section{Prosedur Penelitian}

Menentukan Rumusan Masalah, Menentukan dan Mencari Informasi Pendukung Penelitian, Menentukan Metode Pengumpulan Data, Menentukan Prosedur Pengelolan Data, Pengambilan dan Pengumpulan Data, Pengelohan Data Penarikan Kesimpulan, Pemberian Saran.

\section{Metode Pengumpulan Data Jenis Data}

Jenis data yang digunakan penulis merupakan data kualitatif. Data kualitatif merupakan data yang berbentuk non numerik. Data ini menggunakan penjelasan konkrit dalam bentuk kalimat dalam menjelasakan fakta dan fenomena yang diteliti.

\section{Sumber Data}

Sumber data terbagi atas dua tipe, yaitu data primer dan data sekunder.

1. Data primer adalah data asli yang dikumpulkan sendiri oleh peneliti untuk menjawab masalah penelitiannya secara khusus (Sunyoto, 2011:22). Data ini belum pernah dikumpulkan di periode waktu sebelumnya. Data ini merupakan data utama yang digunakan dalam penelitian, biasanya berbentuk observasi langsung dengan pihak terkait.

2. Data sekunder adalah data yang bersumber dari catatan yang ada pada perusahaan dan dari sumber lainnya (Sunyoto, 2011:23). Data sekunder dalam penelitian ini adalah dokumen yang didapat peneliti pada lokasi penelitian, juga didukung oleh literature, dan penelitian terdahulu.

\section{Teknik Pengumpulan Data}

Teknik dan cara pengumpulan data yang dilakukan adalah sebagai berikut:

1. Penelitian lapangan

Teknik ini dilakukan dengan melaksanakan wawancara dengan pegawai dan pimpinan untuk memperoleh data yang diperlukan dalam penelitian ini. Pengambilan data yaitu pengambilan Daftar nama wajib pajak sarang burung walet, Mekanisme Penetapan dan Pemungutan pajak sarang burung walet yang ada di dinas pendapatan daerah kebupaten minahasa utara, serta datdata lain yang berhubungan dengan penelitian ini.

2. Penelitian kepustakaan

Teknik ini dilakukan dengan cara mendapatkan informasi dari teori-teori dengan cara mempelajari serta mengutip dari buku-buku literature, jurnal, serta bahan-bahan informasi lainnya yang berhubungan dengan masalah yang diteliti.

\section{Metode Analisis}

Analisis data adalah upaya yang dilakukan dengan jalan bekerja dengan data, mengorganisasikan data, memilah-milahnya menjadi satuan yang dapat dikelola, mensintesiskannya, mencari dan menemukan pola, menemukan apa yang penting dan apa yang dipelajari, dan memutuskan apa yang dapat diceritakan kepada orang (Moleong, 2011:248). Penelitian ini menggunakan metode analisis data secara deskriptif. Peneliti mencoba mengolah data yang diperoleh sesuai dengan peraturan bupati dan diolah lewat pendeskripsian sebuah fenomena yang diteliti lewat penjelasan fakta berdasarkan data di lapangan. 


\section{HASIL PENELITIAN DAN PEMBAHASAN}

\section{Deskriptif Objek Penelitian}

Kabupaten Minahasa Utara (sering disingkat Minut) dengan pusat pemerintahan dan ibukota di Airmadidi, terletak di Provinsi Sulawesi Utara. Kabupaten ini memiliki lokasi yang strategis karena berada di antara dua kota, yaitu Manado dan kota pelabuhan Bitung. Dengan jarak dari pusat kota Manado ke Airmadidi sekitar $12 \mathrm{~km}$ yang dapat ditempuh dalam waktu 30 menit. Sebagian dari kawasan Bandar Udara Sam Ratulangi terletak di wilayah Minahasa Utara.

Kabupaten Minahasa Utara terletak di Provinsi Sulawesi Utara yang berjarak $\pm 19 \mathrm{~km}$ dari Ibu Kota Provinsi. Merupakan daerah otonom baru yang dimekarkan dari Kabupaten Minahasa melalui Undang-undang Nomor 33 Tahun 2003 dan diresmikan pada tanggal 7 Januari 2004. Memiliki potensi alam yang luas serta kekayan sejarah dan budaya daerah yang menjadi daya tarik tersendiri Kabupaten Minahasa Utara sebagai daerah tujuan wisata Indonesia di provinsi Sulawesi Utara, sebagaimana Visi Kabupaten Minahasa Utara : "Kabupaten Tujuan Wisata Tahun 2015"

VISI : Minahasa Utara Menjadi Kabupaten Agribisnis, Industri dan Pariwisata Secara Terpadu Serta Berkelanjutan di Tahun 2021.

\section{MISI}

1. Mengembangkan Agribisnis secara efesien dan efektif.

2. Mewujudkan Kawasan Industri Yang Berwawasan Lingkungan Mendukung Kawasan Ekonomi Khusus (KEK) di Kauditan, Kema dan Likupang Raya.

3. Meningkatkan Kualitas Sumber Daya Manusia.

4. Menyediakan Infrastruktur Yang Memadai.

5. Menciptakan Birokrasi Pemerintahan Yang Baik dan Melayani.

\section{Hasil Peneltian}

Tabel 4.1

\begin{tabular}{|c|c|c|c|}
\hline No. & Kecamatan & Desa/Kelurahan & Jumlah \\
\hline 1. & Airmadidi & Kelurahan Sukur & 1 \\
\hline \multirow{3}{*}{2.} & \multirow{3}{*}{ Kema } & Desa Waleo & 1 \\
\hline & & Desa Kema & 3 \\
\hline & & Desa Tontalete & 3 \\
\hline \multirow[t]{4}{*}{3.} & Kauditan & Desa Kaima & 2 \\
\hline & & Desa Lembean & 4 \\
\hline & & Desa Tumaluntung & 1 \\
\hline & & Desa Tontalete & 1 \\
\hline \multirow[t]{3}{*}{4.} & Kalawat & Desa Suwaan & 5 \\
\hline & & Desa Kawangkoan & 1 \\
\hline & & Desa Kolongan & 1 \\
\hline \multirow[t]{10}{*}{5.} & Dimembe & Desa Wasian & 1 \\
\hline & & Desa Tatelu & 1 \\
\hline & & Desa Lumpias & 1 \\
\hline & & Desa Pinilih & 5 \\
\hline & & Desa Talelu & 2 \\
\hline & & Desa Klabat & 7 \\
\hline & & Desa Warukapas & 1 \\
\hline & & Desa Dimembe & 1 \\
\hline & & Desa Matungkas & 1 \\
\hline & & Desa Tetey & 1 \\
\hline \multirow[t]{2}{*}{6.} & Talawaan & Desa Talawaan & 3 \\
\hline & & Desa Mapanget & 1 \\
\hline
\end{tabular}


Tabel 4.1

\begin{tabular}{|l|l|l|c|}
\hline No. & \multicolumn{1}{|c|}{ Kecamatan } & \multicolumn{1}{|c|}{ Desa/Kelurahan } & Jumlah \\
\hline 7. & & Desa Warisa & 3 \\
\hline & Likupang Barat & Desa Palaes & 1 \\
\hline 8. & & Desa Tarabitan & 3 \\
\hline & Likupang Timur & Desa Likupang & 1 \\
\hline & & Desa kaweruan & 5 \\
\hline 9. & Likupang Selatan & Desa Sarawet & 3 \\
\hline & & Desa Kokoleh & 2 \\
\hline & & Desa Kaweruan & 1 \\
\hline & & Desa Batu & $\mathbf{6 9}$ \\
\hline & Total & Desa Wangurer & \\
\hline
\end{tabular}

Sumber: Dinas Pendapatan Daerah, Minahasa Utara

Mekanisme Penetapan dan Pemungutan Pajak Sarang Burung Walet

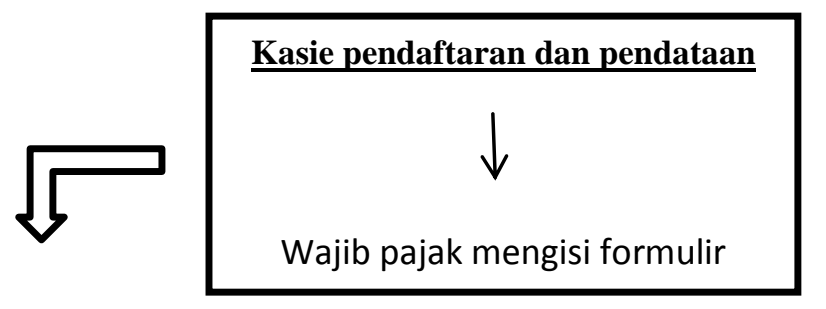

Kasie penetapan
Menerbitkan SKPD
Self assessment $\quad$ Official assesment
Pengesahan skpd
Kabid
Sekretaris
Kepala dinas
(tanda tangan)

Dasar Pengenaan Pajak adalah nilai jual sarang burung walet. Nilai jual merupakan hasil perkalian antara volume produksi dengan harga standar yang ditetapkan Bupati.

Cara Perhitungan :

\section{TARIF PAJAK x DASAR PENGENAAN}

Tarif Pajak $: 10 \%$

Dasar Pengenaan : Nilai Jual Sarang Burung Walet

Harga Standar Sarang Burung Walet ditetapkan sebagai berikut : 


\begin{tabular}{|l|l|l|}
\hline No. & JENIS SARANG & HARGA PER KG \\
\hline 1 & Sarang Sriti & Rp. $400.000,-$ \\
\hline 2 & Sarang Walet Putih & Rp. $14.000 .000,-$ \\
\hline 3 & Sarang Walet Merah & Rp. $10.000 .000,-$ \\
\hline
\end{tabular}

\section{Pembahasan}

Kegiatan pendataan usaha sarang burung walet sebagai objek pajak sekaligus pendataan pemilik/penanggung jawab usaha sarang burung walet sebagai wajib pajak juga melibatkan pihak ketiga seperti Badan Pusat Statistik (BPS) Kabupaten Minahasa Utara. Pendataan yang dilakukan sudah meliputi data utama seperti jenis bangunan, lokasi tempat usaha, luas bangunan, tahun mulai beroperasi, pemilik/penanggung jawab usaha dan alamat pemilik/penanggung jawab usaha. Data yang dihasilkan tidak memberikan informasi tentang luas bangunan rumah walet, serta sebagian usaha sarang burung walet belum diketahui nama dan alamat pemilik/penanggung jawab usahanya. Data dan informasi yang dihasilkan dari kegiatan pendataan usaha sarang burung walet ini nantinya akan digunakan sebagai dasar bagi Dinas Kabupaten Minahasa Utara untuk mendaftarkan usaha wajib pajak, apabila wajib pajak tidak mendaftarkan sendiri usahanya, sebagaimana yang telah diatur dalam Peraturan Bupati Nomor 24 Tahun 2012 tentang Pelaksanaan dalam tata cara pendaftaran dan pendataan pajak sarang burung walet kabupaten Minahasa Utara, yang berpedoman pada undang-undang perpajakan daerah serta sistem dan prosedur pajak daerah.

Proses pemungutan pajak sarang burung walet yang diatur dalam Peraturan Bupati Kabupaten Minahsa Utara dilakukan melalui tahapan seperti yang telah dijelaskan pada halaman sebelumnya dalam hasil penelitian dapat dilihat pada Bagian Mekanisme pemungutan. Dari rangkaian proses pemungutan pajak sarang burung walet seperti yang terlihat pada bagian tsb menjelaskan bagaimana mekanisme pengelolaan pemungutan pajak daerah khusus pajak sarang burung walet.

Upaya yang telah dilakukan Pemerintah Kabupaten Minahasa Utara dalam rangka pemungutan pajak sarang burung walet diantaranya dengan melakukan sosialisasi tentang pajak sarang burung walet dan tata cara pengurusan izin usaha sarang burung walet, Kemudian Kepala Dinas Pendapatan kabupaten Minahasa Utara mengeluarkan Surat Perintah Tugas. Surat Perintah Tugas tersebut ditujukan kepada Tim Intensifikasi Sumber-sumber Penerimaan Pendapatan Asli Daerah (PAD) dalam rangka pemutakhiran data potensi pajak daerah Pemerintah Kabupaten Minahasa Utara.

Target Nilai penerimaan pajak sarang burung walet di kabupaten Minahasa Utara sebesar Rp. 30.000.000,-/tahun, karena untuk pajak sarang burung walet masih tergolong kecil dibanding pajak-pajak yang lain. Nilai penerimaan untuk saat ini sudah memenuhi target penerimaan pajak sarang burung walet yang telah ditetapkan Pemerintah Kabupaten Minahasa Utara. Dengan kata lain, target penerimaan pajak sarang burung walet yang telah ditetapkan Pemerintah Kabupaten Minahasa Utara sudah tercapai untuk bisa membantu penerimaan daerah.

\section{Kesimpulan}

\section{PENUTUP}

1. Mengenai Penetapan Pajak, Menurut Peraturan Bupati Nomor 24 Tahun 2012 Pajak Sarang Burung Walet yang dilakukan oleh Dinas, berpedoman pada undang-undang perpajakan daerah serta sistem dan prosedur pajak daerah.

2. Peraturan Daerah dan Peraturan Bupati tentang pajak sarang burung walet yang sudah diterapkan dengan baik sampai sekarang hingga rangkaian proses pemungutan pajak sarang burung walet bisa mencapai target penerimaan sesuai dengan peraturan yang berlaku.

\section{Saran}

Untuk meningkatkan pendapatan pajak sarang burung pemerintah daerah dapat melakukan upaya optimalisasi intensifikasi pemungutan pajak daerah terutama pajak sarang burung. Hal ini dapat dilakukan dengan pemberian sanksi tegas terhadap para wajib pajak yang tidak mentaati peraturan pajak yang berlaku. 


\section{DAFTAR PUSTAKA}

Fitriandi, Yuda Aryanto, Agus Puji Priyono, 2010. Kompilasi Undang-Undang Perpajakan Terlengkap. Salemba Empat. Jakarta

Ilyas, B, Wirawan dan Richard Burton, 2010. Hukum Pajak. Salemba Empat. Jakarta

Mardiasmo, 2011. Perpajakan Edisi Revisi 2011. Penerbit Andi. Yogyakarta.

Maulana, Ahmad, 2012. Analisis Potensi dan Upaya Pemungutan Pajak Sarang Burung Walet. Universitas Indonesia. Jakarta

Nurhidayati, 2010. Evaluasi Penerimaan Pajak Sarang Burung Walet di Kota Bengkulu. Universitas Indonesia. Jakarta

Siti, Resmi, 2009. Perpajakan: Teori dan Kasus. Salemba Empat. Jakarta

Suandy, Erly, 2011. Hukum Pajak Edisi 5. Salemba Empat. Jakarta

Sugiyono, 2012. Metode Penelitian Pendidikan (Pendekatan Kuantitatif, Kualitatif, dan R\&D). Alfabeta. Bandung

Sunyoto, Danang, 2011. Metodologi Penelitian Ekonomi. CAPS Publishing. Yogyakarta

Tanjung, Abdul Hafiz, 2009. Penatausahaan dan Akuntansi Keuangan Daerah untuk SKPD, Edisi 2. Salemba Empat. Jakarta

Tmbooks, 2013. Perpajakan: Esensi dan Aplikasi. Penerbit Andi. $\quad$ Yogyakarta

Waluyo, 2010. Perpajakan Indonesia Edisi 9. Salemba Empat. Jakarta , 2011. Perpajakan Indonesia Edisi 10. Salemba Empat. Jakarta 